\title{
Uncultivated Plants and Livelihood Support - A case study from the Chepang people of Nepal
}

\author{
Kamal Prasad Aryal, Åke Berg and Britta Ogle
}

\section{Research}

\begin{abstract}
This study documents the use of uncultivated plants, their status and contribution to the livelihoods of Chepang people in the mid-hills of Nepal. Diversity fairs, key informant surveys, group discussions and individual household surveys were conducted. The plants identified were used as food, vegetables, medicine, and for cultural and economic reasons. The uses of 85 uncultivated plant species were documented of which $72 \%$ had multiple functions. The uncultivated foods contributed significantly to food requirements of the households (mean 2.6 months a year). Fifteen species were stored for future use, e.g., Dioscorea species. Almost all species (87\%) were also culturally important or medicinal $(43 \%)$. The availability of these species has declined over time. However, people have started in-situ conservation and domestication of several important species, e.g., Asparagus racemosus Willd., Dioscorea bulbifera L., and Diploknema butyracea (Roxb.) H.J. Lam, but these resources are neglected in research and development activities.
\end{abstract}

\section{Introduction}

Throughout the world, wild or uncultivated plants provide a 'green social security' to hundreds of millions of people in the form of food, materials for clothes and shelter (Cunningham 2001). These plants add diversity to local food systems, reinforce culture and contribute with diversity to farming systems, and could be important for household food security, health, and nutrition and income generation (Machakaire 2001, Scoones et al. 1992, Warinwa 2000). Foods from uncultivated species forms an integral part of the daily diets of many rural households (Cromwell 1997, Shrestha 2001). Between $60-70 \%$ of populations in developing countries living between agricultural and forest land areas collect various parts of uncultivated plants such as roots, leaves, fruits, and nuts (Heywood 1999, Hladik \& Dounias 1993).
For instance, Shore (2000) indicated that in Bangladesh uncultivated foods such as leafy greens, tubers and wild fruits constituted nearly $40 \%$ of food requirements of communities. In rural India local people consumed uncultivated foods at least 50-80 days in a year (DDS 2002). In addition to providing food directly, uncultivated plants provide an opportunity for cash generation (Harris \& Mohammed 2003). Many uncultivated plant resources have significant economic value derived from their collection and sale (Melnyk 1994). Moreover, uncultivated food is an important component of the local society and culture, and loss of those means a loss of important components of culture and religion (Akhtar 2001). Uncultivated plants are also used as folk medicines for common ailments such as headache, swellings, wounds, scabies, and digestion problems (DDS 2002).

Over $90 \%$ of the Nepalese people live between farmland and forest, and they depend on natural resources for their basic needs. In particular, the hill people depend on a combination of forest products, livestock and agricultural products, and their livelihoods would not be sustainable without these resources (Manandhar 1995, 2002). Ary-

\section{Correspondence}

Kamal Prasad Aryal, International Centre for Integrated Mountain Development (ICIMOD), GPO Box 3226, Kathmandu, NEPAL. karyal@icimod.org

Åke Berg, Swedish Biodiversity Centre (CBM), SLU, SE-750 07 Uppsala, SWEDEN. Ake.Berg@cbm.slu.se

Britta Ogle, Department of Rural and Urban Development, SLU, SE-750 07, Uppsala, SWEDEN.

Ethnobotany Research \& Applications 7:409-422 (2009)

Published: December 2, 2009 
al \& Awasthi (2004) showed that about two thirds of the households in hill districts of Nepal suffer from food shortages due to insufficient agricultural production on available land.

Shifting cultivation is the traditional land-use for farmers from various ethnic groups in Nepal, and is practiced in about 20 districts (Regmi et al. 2003). The Chepang of central Nepal are one of the ethnic groups known for practicing shifting cultivation, but also for being among the most marginalized communities (Kerkhoff \& Sharma 2006). Food security is a major concern, and a study in Kharsang village, where $47 \%$ of the population were Chepang, showed that $97 \%$ of the people suffered from varying degrees of food deficiency during 3-9 months per year (Balla et al. 2002). Because the land is hardly fit for permanent cultivation, the ability to practice shifting cultivation contributes to their subsistence, but this practice might lead to periods of food insecurity. The search for wild and uncultivated foods might therefore be an important supplement for livelihood support (Aryal et al. 2007).

Diversity of uncultivated plant species, their occurrence and relationship with cultivated species and their use by humans has rarely been studied systematically (Grivetti \& Ogle 2000, Vázquez-García et al. 2004). The value and potential of uncultivated foods in the food security and nutrition of rural people is also neglected in agricultural and environmental programs (Gari 2002, Ogle 2001, Ogle et al. 2003). Little is known about the large variety of land use types, cultural knowledge of indigenous people and the vast number of uncultivated plant species associated with shifting cultivation by policy makers, authorities and scientists (Kerkhoff \& Sharma 2006). Some uncultivated plant species are probably used by many rural households in Nepal in the daily life. However, detailed studies about their availability, status, and contribution in the livelihood support are few (Regmi et al. 2006, Shrestha 2001, Shrestha \& Dhillion 2006).

In this study we investigated the use of uncultivated plants for foods, medicines, cultural purposes and their importance as income generation sources among Chepang communities in the Dhading district of Nepal. The principle aim was to identify uncultivated plant species and understand their status and contribution to the livelihood support of the Chepang people. We hypothesized that uncultivated plants were important for livelihood support and income for the Chepang community.

\section{Materials and methods}

\section{Study site and study population}

The field research was conducted in Bumrang village of Dhusa Village Development Committee (VDC) in the Dhading districts of Nepal (Figure 1). Dhading is situated in the central development regions of Nepal between $27^{\circ}$

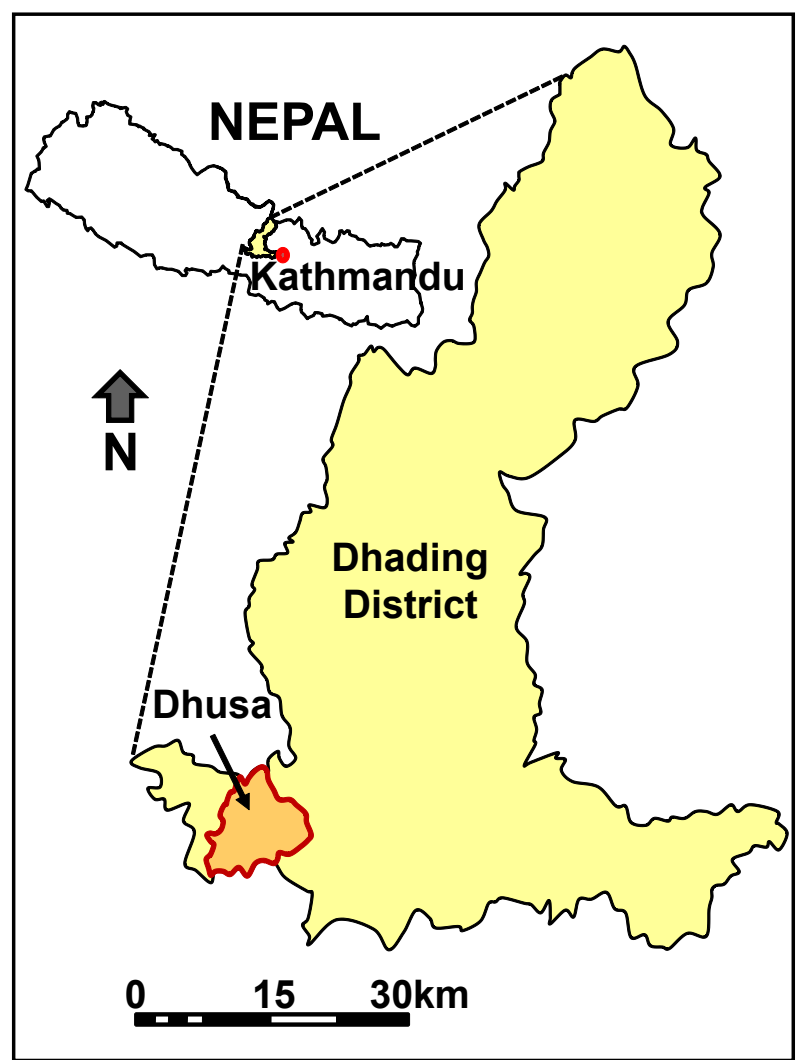

Figure 1. Location of the study area (Dhusa Village Development Committee) in the Dhading district in the middle hills of Nepal. Modified from map prepared by ICIMOD April, 2007 used in Aryal 2007.

$40^{\prime}$ to $28^{\circ} 14^{\prime} \mathrm{N}$ and $84^{\circ} 0^{\prime}$ to $85^{\circ} 1^{\prime} \mathrm{E}$ (Rimal et al. 2002). The study site is situated at elevations of 450 to $1400 \mathrm{~m}$ above sea level with warm sub-tropical to temperate climate. The area is sensitive to erosion due to steep hill slopes. The number of households of the VDC is 1012 (CBS 2003).

The population of Chepangs in Nepal total about 52,000 $(0.23 \%$ of Nepal's population) and are considered to be one of the less developed communities with only $13.9 \%$ being literate (CBS 2003). Chepangs are the ancient settlers of the study area with 350 households recorded in the VDC (Chepang District Profile 2006). Chepangs have traditionally lived as semi-nomads depending on shifting cultivation farming systems supplemented with hunting and gathering of uncultivated foods (Chepang 2006, Manandhar 2002). The major crops are maize (Zea mays L.) and finger millet (Eleusine coracana (L.) Gaertn.). The household production is generally sufficient for about 5 months subsistence per year and only $1 \%$ of the Chepang have sufficient food for the whole year from their own agricultural production (Gurung 2006). During the rest of the year they depend on wage labor work and uncultivated foods (Regmi et al. 2006). 


\section{Aryal et al. - Uncultivated Plants and Livelihood Support - A case study from the Chepang people of Nepal}

\section{Methods}

The main methods used for identification of uncultivated plants that were being used were 1) diversity fairs, 2) key informants interviews and group discussions, and 3) individual household surveys.

Diversity fairs of uncultivated foods were organized in the study site with the objective of quickly assessing the general richness and status of uncultivated plants. Diversity fairs provided unique opportunities for individuals and community members to display their local plant material, as well as to share and document associated knowledge (Rijal et al. 1998, Sthapit et al. 2003). During the fair, specimens of uncultivated plant species were collected, identified, and vouchers were deposited at the district office of Nepal Chepang Association (NCA), Chepang Sangrahalaya (Chepang Museum), Dhading. These fairs were useful for identifying the uncultivated species, and their use values. Important species were collected for group discussions about different species habitat and, uses as foods, vegetables, medicines, or in cultural ceremonies.

Ten key informants (seven farmers and three people from the staff at local institutions) were selected for interviews. The community people identified the farmers whereas the researchers identified the informants from local institutions. Key informants were considered to have good knowledge about the local people in general and about use of uncultivated plants in particular. All initially selected key-informants agreed to participate in the study. Key informants were interviewed about their perceptions and experience concerning the role of uncultivated foods in sustainable livelihoods, and conservation actions taken to maintain these species. During repeated visits to the study site further group discussions (8-12 people) were held with: i) old-age key informants, and ii) with women who the key-informants knew were especially skilled in the use of uncultivated plants.

Sixty-two households (18\% of the households) were selected for interviews by using random sampling of all households. All households were visited at least once for approximately three hours (some household were visited twice for verification). The household survey was designed to get data on farming practices, subsistence, use of uncultivated plants and their management, as well as personal demographic features. The household survey questionnaire consisted of four sections. The first section consisted of demographic and socio-economic information on the household, including variables such as sex, age, wealth categories, education, household size, major occupation, food sufficiency, and household income. The second section concerned information about the shifting cultivation practices and the third section concerned uncultivated plant species. The final section concerned information about the conservation and management of uncultivated plant species.
In addition, field visits were made with the key informants to areas where the respondents collected the uncultivated species. During the visits, harvesting methods, parts used, harvest quantity as well as treatment and storage of different species for future use was discussed in semistructured and open-ended interviews.

\section{Results and Discussion}

\section{General features of the respondents}

The farmers in the study site live under different socioeconomic conditions in terms of education, income sources, food sufficiency levels, family size, age and occupation. The number of interviewed persons was 62 (37 men and 25 women). The mean age of the respondents was 39 years $(44.5 \%$ of the respondents were older than 41 years and $42 \%$ were $26-40$ years old.) The average household size of the study site was 6.5 people, which is somewhat higher than the national average of 5.4 persons (CBS 2003). In general, the literacy rate was very low; $73 \%$ of the respondents were illiterate and only $27 \%$ could write their own name. This can be compared to the national literacy rate of $54 \%$ (CBS 2003). The average yearly household income was $\$ 209$. Food sufficiency was a major problem in the area; about $70 \%$ of the households could only live 7-10 months on products from their own agricultural production and $16 \%$ of the households could live less than 6 months a year on their own agricultural production. During the food deficit periods, these households depended on multiple coping strategies such as share cropping, i.e., growing of crops on land owned by others, ( $40 \%$ of the households), wage labour $(90 \%)$, collection of wild foods (92\%), and selling of products $(24 \%$ of the households). All households used uncultivated plants however, the quantity and forms of use differed widely between the households due to socio-economic and cultural factors (see below).

\section{Richness of uncultivated plants and their status}

Uncultivated plants in this study include all plant resources that are collected for human consumption from natural and semi-natural environments (e.g., slash and burn areas, agriculture fields, grasslands with natural vegetation). However, the term 'uncultivated' does not necessarily imply a total absence of human influence because plants may be collected from common property areas in some regions but protected and managed in home gardens in other areas (Cromwell et al. 1997).

Diversity fairs in the area recorded a total of 85 uncultivated plant species (see Appendix 1). Of these, 61 species $(72 \%)$ had multiple functions as food, medicine, or had cultural or economic importance. Most of the recorded species are also used in other parts of the country (Manandhar 2002, Shrestha 2001, Shrestha \& Dhillion 2006). 
The availability of most uncultivated plants (62\%) was classified as intermediate (medium availability and possible to use on a daily basis). For $20 \%$ of the species, the status in the wild was classified as scarce (difficult to find, and could not be used as much as desired), and $18 \%$ of the species as abundant in their natural habitat (sufficiently available and could be used as much as desired regularly). Interestingly, almost all the species with low availability were those used for medicinal purposes or species used for their food value. The collection and marketing of Asparagus racemosus Willd., Cissampelos pareira L., Dioscorea bulbifera L., Juglans regia L., Swertia chirayita (Roxb. ex Fleming) Karsten, Tectaria macrodonta (Fée) C. Chr., Terminalia chebula Retz., and Tinospora sinensis (Lour.) Merr. have been shown to have good profitability (Manandhar 2002). However, over-exploitation and illegal harvesting and trading are threatening some of these species (Chaudhary 1999). Similarly, uncultivated plants are over-exploited in other parts of the worlds (Balemie \& Kebebew 2006, Begossi et al. 2002, Gari 2002, Tabuti et al. 2004). During group discussions, decreasing forest cover, heavy dependency of people on these resources and illegal harvesting and trade were suggested as the major causes for perceived declining abundance of these species.

\section{Use of uncultivated foods}

All respondents reported that they use uncultivated resources in their daily life. $94 \%$ of all households responded that they used uncultivated foods due to insufficiency and because they are freely available. Medicinal value $(43 \%$ of all households) and nutritional aspects (32\% of all households) were also mentioned by a relatively large proportion of the respondents. A conclusion from the group discussions was that the use of medicinal plants for health care is declining. An important reason for this change is that the traditional healers, who used to treat people, are few at present and the transfer of knowledge and practice to prepare such medicines is low. The younger generation is not interested in studying such traditional ways of medication (Bista 2004, Ladio \& Lozada 2004).

The uncultivated foods contributed significantly to the food requirements of the households. A majority (58\%) of the households used food from uncultivated sources more than 3.5 months per year (Figure 2). Similar contributions from uncultivated foods have been found by Balla et al. (2002) in the Tanahun and Chitwan districts of Nepal. Shrestha (2001) reported that $20-30 \%$ of the food requirements in rural communities of Nepal were met by uncultivated food crops.

The importance of uncultivated foods is supported by studies in other countries. For instance, a study carried out in India, reported that the poor consumed uncultivated crops at least $50-80$ days in a year, but also that these resources used to have larger importance in the past (DDS

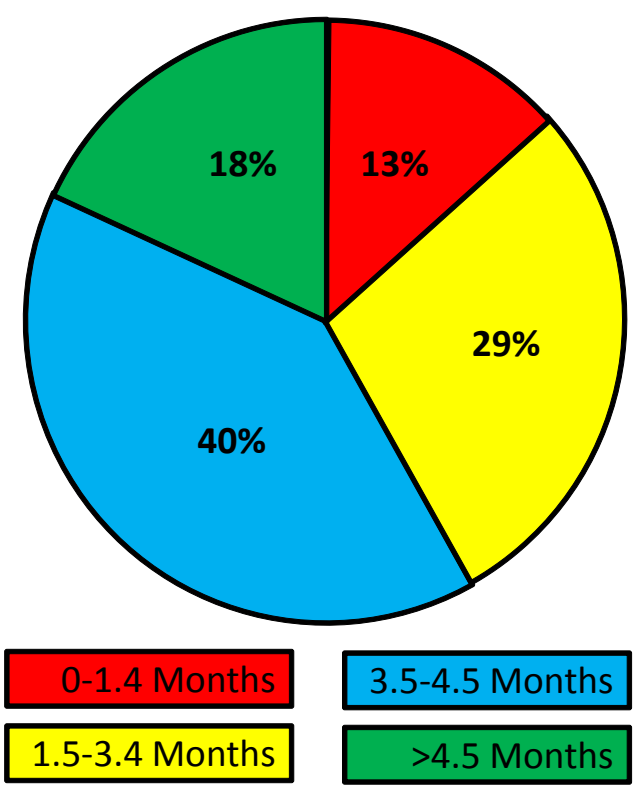

Figure 2. Contribution of uncultivated foods to food support in Dhading District, Nepal study site. Percentage of households $(n=62)$ depending on uncultivated food crops for time periods of different length during a year.

2002). Similarly, Shore (2000) reported that in communities in Bangladesh $40 \%$ of the food requirement came from uncultivated foods, and in a study in Burkina Faso Smith et al. (1995) reported that $20 \%$ of all food items were from the wild. Cromwell et al. (1997) showed that the value of all wild plant resources to rural communities was calculated to be more than $8 \%$ of the agricultural gross domestic product (GDP) in Tanzania. Thus, contributions to the food supply by uncultivated plants are considerable but they vary between regions and ethnic groups (Heywood 1999).

In our study, uncultivated foods were less important as a source for income (only about $4 \%$ of the households reported that uncultivated foods contributed significantly to their income), but people have started to sell some species with potential market value. In fact, $11.3 \%$ of the households had started to sell $A$. racemosus, Castanopsis indica (Roxburgh ex Lindl.) A.DC., Diploknema butyracea (Roxb.) H.J. Lam, Dryopteris cochleata (D. Don) C. Chr., Phyllanthus emblica L., Tamarindus indica L., and Thysanolaena maxima (Roxb.) Kuntze although in small amounts at present but with significant potential in the future as the demand rises in the market. The selling of uncultivated foods is not new in this area however; there were people who used to collect and sell products originating from other areas with a tradition of marketing wild foods and products. Other studies have shown that many uncultivated plant resources have significant economic value by preventing the need for cash expenditures, and income derived from the collection and sale of these re- 


\section{Aryal et al. - Uncultivated Plants and Livelihood Support - A case study from the Chepang people of Nepal}

Table 1. Frequently used uncultivated plant species in Dhading District, Nepal study site.

\begin{tabular}{|c|c|c|c|c|c|c|c|c|c|c|c|}
\hline \multirow[t]{2}{*}{ Species } & \multirow[t]{2}{*}{ Plant types } & \multicolumn{9}{|c|}{ Uses } & \multirow[t]{2}{*}{ Parts used } \\
\hline & & $\begin{array}{l}\frac{\pi}{2} \\
\frac{2}{3} \\
\frac{ \pm}{3}\end{array}$ & 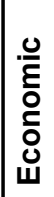 & \begin{tabular}{l} 
D \\
$:$ \\
\hdashline
\end{tabular} & 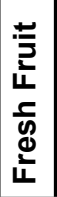 & 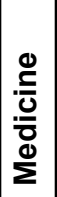 & $\frac{g}{\frac{g}{x}}$ & 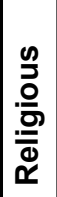 & $\begin{array}{l}7 \\
0 \\
0 \\
14 \\
0 \\
\frac{0}{0} \\
\frac{0}{0} \\
\text { ம }\end{array}$ & 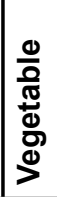 & \\
\hline Arundinaria falcata Nees & Short type bamboo & & $X$ & & & & & & & & Stem \\
\hline Asparagus racemosus Willd. & Straggling, slender shrub & & & & & $x$ & & & & $X$ & Tender shoots \\
\hline $\begin{array}{l}\text { Castanopsis indica (Roxburgh } \\
\text { ex Lindl.) A.DC. }\end{array}$ & Evergreen tree & & & $x$ & & & & & & & Cotyledons \\
\hline $\begin{array}{l}\text { Crataeva unilocularis Buch. } \\
\text {-Ham. }\end{array}$ & Deciduous tree & & & & & & & & & $X$ & $\begin{array}{l}\text { Tender leaves } \\
\& \text { buds }\end{array}$ \\
\hline Dioscorea bulbifera L. & $\begin{array}{l}\text { Perennial herbaceous } \\
\text { climber }\end{array}$ & & & & & & & & $x$ & & Tubers \\
\hline $\begin{array}{l}\text { Dioscorea deltoidea Wall. } \\
\text { ex Griseb. }\end{array}$ & Climbing herb & & & & & & & & $X$ & $X$ & Tubers \\
\hline $\begin{array}{l}\text { Diploknema butyracea (Roxb.) } \\
\text { H.J. Lam }\end{array}$ & Deciduous tree & $x$ & $x$ & & $x$ & & & & & & Juicy pulp, seed \\
\hline $\begin{array}{l}\text { Dryopteris cochleata (D. Don) } \\
\text { C. Chr. }\end{array}$ & Terrestrial fern & & & & & & & & & $X$ & Tender shoots \\
\hline Phyllanthus emblica L. & Deciduous tree & & $x$ & & & & $x$ & & & & Fruits \\
\hline Rubus ellipticus Sm. & Straggling shrub & & & & $X$ & & & & & & Ripe fruits \\
\hline Schima wallichii (DC.) Korth. & Evergreen tree & & & & & & & $\mathrm{X}$ & & & Fruits, leaves \\
\hline Urtica dioica $\mathrm{L}$. & Perennial herb & & & & & & & & & $X$ & $\begin{array}{l}\text { Tender shoots } \\
\text { \& leaves }\end{array}$ \\
\hline
\end{tabular}

sources could be important for poor people as a source of cash (Guinand \& Lemessa 2001, Melnyk 1994).

\section{Frequently used species and their use}

The most frequently used species reported by informants and their uses are presented in Table 1. These include trees, shrubs and herbs that were mainly used as vegetables and other foods.

Information on the frequency of harvest and use was compiled for species that were often used (Table 2). Species used as staple foods were harvested from one to more than 25 times per month. D. bulbifera and $D$. deltoidea were harvested regularly and used more than 20 times a month by a large proportion of the households. Other Dioscorea species were harvested and used on a regular basis although not as frequently as the two species above (Table 2). Several of the species can be stored for future use and therefore the frequency of harvest was lower than the frequency of use (Table 2). The most commonly stored species were $D$. bulbifera
(95\% of the households) and $D$. deltoidea (42\%). Both species were prioritized food crops in the area. Collection of these species has shown that people used to harvest up to $50 \mathrm{~kg}$ per harvest. The analysis on the quantity per harvest showed that $71 \%$ of the household used to harvest $11-30 \mathrm{~kg}$ per harvest.

People in the study site also stored uncultivated staple foods, vegetables and medicines for future use. The uncultivated starchy foods and vegetables were processed

Table 2. Proportion of households with different frequency of harvest/ use of important food species each month in Dhading District, Nepal study site.

\begin{tabular}{|l|c|c|c|c|c|}
\hline \multirow{2}{*}{ Species } & \multicolumn{5}{|c|}{ Frequency of harvest/use per month } \\
\cline { 2 - 6 } & $1-6$ & $7-12$ & $13-18$ & $19-24$ & $>25$ \\
\hline Dioscorea bulbifera L. & $31 / 0$ & $37 / 5$ & $23 / 8$ & $8 / 32$ & $2 / 55$ \\
\hline $\begin{array}{l}\text { Dioscorea deltoidea Wall. } \\
\text { ex Griseb. }\end{array}$ & $44 / 5$ & $27 / 27$ & $18 / 21$ & $6 / 27$ & $2 / 16$ \\
\hline Dioscorea pentaphylla L. & $71 / 39$ & $42 / 44$ & $13 / 26$ & $3 / 21$ & $0 / 0$ \\
\hline $\begin{array}{l}\text { Dryopteris cochleata (D. } \\
\text { Don) C. Chr. }\end{array}$ & $40 / 19$ & $10 / 27$ & $5 / 6$ & $2 / 3$ & $0 / 0$ \\
\hline Urtica dioica L. & $0 / 0$ & $10 / 11$ & $31 / 27$ & $31 / 32$ & $21 / 21$ \\
\hline
\end{tabular}


in local ways for storage to prolong their availability. Some uncultivated starchy foods like $D$. bulbifera are cut into small slices and dried either under sun light or hung above a fire place to dry before storing in an airtight container for future use. Similarly, vegetables were sun dried when fresh while others are boiled or blanched, for later use during the dry season (see also Dhillion \& Shrestha n.d., Gautam et al. 2006, Ngugi 2000, Regmi et al. 2006, Sullivan 2000).

\section{Conservation and management practices}

The focus group discussion and interviews of key informants suggested that the availability of the uncultivated foods from the area has declined during the last 40 years. During the group discussions $90 \%$ of the people had the opinion that 40 years ago, i.e., in 1965, uncultivated food availability was not a problem the availability of uncultivated foods since then has been halved. More than $70 \%$ of the informants mentioned that the major reasons for such changes were the depletion of natural vegetation and uncontrolled harvesting due to heavy dependency of local people on uncultivated plants. These factors are also often cited as underlying causes of the decline in use of uncultivated resources in other studies (Akhtar 2001, Fouere et al. 2000).

$98 \%$ of respondents reported that they are involved in management of uncultivated plant species. Moreover, $90 \%$ mentioned that they are doing in-situ conservation of wild populations and $71 \%$ mentioned domestication as a major way of maintaining these uncultivated food resources. However, farmers also suggested two other factors to facilitate sustainable use of uncultivated food plants: i) increased awareness (17\% of the households), and ii) restrictions in the use of these plant resources $(36 \%)$. Fewer households suggested technical solutions or increased cooperation between households. A general conclusion from group discussions and key informant interviews was that participatory natural resources management programs are needed to encourage local people to work with conservation and management of these natural resources.

This study showed that people in the study site have been using uncultivated resources for generations and, because of their close associations with nature and natural system, have developed sophisticated knowledge systems (Etkin 2002) about the plants and their ecosystems. However, the present trends in harvesting of some of the species are probably not sustainable and the way of harvesting negatively impacts the species availability in the future (see also Chaudhary 1999, Dhillion \& Shrestha n.d., Shrestha \& Dhillion 2003). Policy support mechanisms, especially on effective management and conservation of uncultivated species, are lacking (Kerkhoff \& Sharma 2006, Shrestha 2001). It would be a tragedy if people such as the Chepang who maintain their livelihoods by the combination of different strategies such as gathering of uncultivated foods, hunting, wage labouring and subsistence agriculture (shifting cultivation) lost a key component of their food, i.e., uncultivated plants.

\section{Conclusions}

This study has revealed that the Chepang people of $\mathrm{Ne}$ pal continue to rely on uncultivated plant species for consumption at times of food shortage and that these species have the potential to become valuable staple foods and important alternatives to the usual food crops cultivated by farmers. Analysis of the use of species such as Dioscorea showed that there is a growing pressure on wild plant resources, which suggests that there is an urgent need for an awareness program among the local people. There is a need of integrated research and development programs for forest dwelling communities such as the Chepang in Nepal who have food sufficiency problems, where uncultivated foods provide key supplements to the main diet and are of considerable medicinal and cultural importance. Without an understanding of the relationship between staple crop foods and uncultivated food intake, agricultural planning will continue to be dominated by few major crops and exclude diverse and important resources. The contribution of uncultivated plants needs to be taken into account in planning. Rural families in the study site involved in the use of such species are specifically poor, so investment in the development of these resources will make a major contribution to the alleviation of poverty.

\section{Literature Cited}

Akhtar, F. 2001. Uncultivated food in the context of poor people's livelihood: A Nayakrishi experience. Pp. 8-17 in The Proceedings of the Regional Workshop on Uncultivated Foods and Biodiversity. Edited by M.M. Johnston. September 24 to 26, Kathmandu, Nepal. USC CanadaNepal, Kathmandu.

Aryal, K.P. 2007. Uncultivated Plants: An option for livelihood support of the people in mid-hills of Nepal. M.S. Thesis. Swedish Biodiversity Centre, Upsala.

Aryal G.R. \& G.S. Awasthi. 2004. Agrarian Reform and Access to Land Resource in Nepal: Present status and future perspective/action. ECARDS review paper (Unpublished). Environment, Culture, Agriculture, Research and Development Services (ECARDS), Kathmandu, Nepal

Aryal, K.P., B.R. Regmi, P.K. Shrestha \& B.B. Tamang 2007. How can research and development help upland farmers improve their farming systems? Experiences in participatory technology development. Pp. 287-302 in Proceedings of the International Conference on Sustainable Sloping Lands and Watershed Management: linking research to strengthen upland policies and practices. Ed- 


\section{Aryal et al. - Uncultivated Plants and Livelihood Support - A case study from the Chepang people of Nepal}

ited by L. Gebbie, A. Glendinning, R. Lefroy-Braun \& M. Victor. NAFRI, Vientiane, Laos.

Balemie, K. \& F. Kebebew. 2006. Ethnobotanical study of wild edible plants in Derashe and Kucha Districts, South Ethiopia. Journal of Ethnobiology and Ethnomedicine 2:53.

Balla, M.K., K.D. Awasthi, P.K. Shrestha, D.P. Sherchan \& D. Poudel. 2002. Degraded Lands in Mid-hills of Central Nepal: A GIS appraisal in quantifying and planning for sustainable rehabilitation. LI-BIRD, Pokhara, Nepal.

Begossi, A., N. Hanazaki \& J. Tamashiro. 2002. Medicinal plants in the Atlantic forest (Brazil) knowledge, use and conservation. Human Ecology 30:281-299.

Bista, D.B. 2004. People of Nepal. Ratna Pustak Bhandar, Kathamandu.

CBS. 2003. Central Bureau of Statistics. Statistical Year Book of Nepal. National Planning Commission Secretariat, HMG/Nepal. Kathmandu.

Chaudhary, R.P. 1999. Biodiversity prospecting in NepalConstraints and opportunities. Pp. 256-260 in Proceedings of the 8th International Workshop on BIO-REFOR. November 28 - December 2, 1999, Kathmandu, Nepal. BIO-REFOR, IUFRO/SPDC, Kathmandu.

Chepang, P. 2006. Chepangharuko Jatiya Pahichan. Pp. 14-15 in Chepang Awaz (In Nepali). Nepal Chepang Association, Kathmandu, Nepal.

Chepang District Profile. 2006. A Socio-economic and Demographic Information of Chepang in Dhading Districts. A draft report (Unpublished) Nepal Chepang Association, Gajuri, Dhading, Nepal.

Cromwell, E., D. Cooper \& P. Mulvany. 1997. Agriculture, Biodiversity and Livelihoods. Issues and entry points for development agencies. www.ukabc.org/odi_agbiod.pdf Accessed 21 December 2005.

Cunningham, A.B. 2001. Applied Ethnobotany: People, wild plant use and conservation. Earthscan Publications Ltd, London.

DDS. 2002. Deccan Development Society. Uncultivated Food and Poor. www.indiatogether.org/agriculture/dds/ uncultivated.htm Accessed 13 May 2007.

Dhillion S.S. \& P.M. Shrestha. n.d. Conservation needs and regulations for locally managed forests in the Highlands of Dolakha District, Nepal. in Environmental and Development Aspects of Natural Resource Management in Mountains. edited by $\mathrm{H}$. Salleh \& S. Aziz. Pelanduk Press, Singapore, in press.
Etkin, N.L. 2002. Local knowledge of biotic diversity and its conservation in rural Hausaland, Northern Nigeria. Economic Botany 56:73-88.

Fouere, T., B. Maire, F. Delpeuch, Y. Martin-Prevel, F. Tchibindat \& G. Adoua-Oyila. 2000. Dietary changes in African urban households in response to currency devaluation: Foreseeable risks for health and nutrition. Public Health Nutrition 3:293-301.

Gari, J.A. 2002. Agrobiodiversity, Food Security and HIV/ AIDS Mitigation in Sub-Saharan Africa. Strategic issues for agricultural policy and programme responses. www. fao.org/sd/2002/PE0104a_en.htm Accessed 23 April 2007.

Gautam, R., R. Suwal \& P.K. Shrestha. 2006. Status of home gardens of Nepal: Findings of baseline survey conducted in four sites of home garden project. Pp 54-65 in Enhancing the Contribution of Home Gardens to On-Farm Management of Plant Genetic Resources and to Improve the Livelihoods of Nepalese Farmers: Lessons learned and policy implications. Proceedings of home garden workshop, 6-7 August 2004, Pokhara, Nepal. Edited by R. Gautam, B.R. Sthapit \& P.K. Shrestha. LI-BIRD, Bioversity International and SDC, Kathmandu.

Grivetti, L. E. \& B.M. Ogle. 2000. Value of traditional foods in meeting macro- and micronutrient needs: The wild plant connection. Nutritional Research Reviews 13:31-46.

Guinand, Y. \& D. Lemessa. 2001. Wild-food Plants in Southern Ethiopia: Reflections on the role of 'faminefoods' at a time of drought. United Nations Development Programmes and Emergency Unit for Ethiopia. Addis Ababa.

Gurung, B. 2006. Chepang mainstreaming programme, a brief introduction. Chepang Awaz (Voice of Chepang) [a monthly newsletter in Nepali language] March:4-10.

Harris, F. M.A. \& S. Mohammed. 2003. Relying in nature: Wild foods in Northern Nigeria. Ambio 32:24-29.

Heywood, V. 1999. Use and Potential of Wild Plants in Farm Households. Editorial Group, FAO Information Division, Rome.

Hladik, A. \& E. Dounias. 1993. Wild yams of the American rain forest as potential food resources. Pp. 163-176 in Tropical Forests, People and Food. Biocultural interactions and applications to development. Edited by C.M. Hladik, A. Hladik, O.E. Linares, H. Pagezy, A. Semple \& M. Hadley. UNESCO and The Parthenon Publishing Group, New York.

Kerkhoff, E. \& E. Sharma. 2006. Debating Shifting Cultivation in the Eastern Himalayas: Farmers' innovations as le- 
sions for policy. International Centre for Integrated Mountain Development (ICIMOD), Kathmandu.

Ladio, A.H. \& M. Lozada. 2004. Patterns of use and knowledge of wild edible plants in distinct ecological environments: A case study of a Mapuche community from northwestern Patagonia. Biodiversity and Conservation 13:1153-1173.

Machakaire, V. 2001. Comparing and Contrasting Different Research Approaches on Semi- and Uncultivated Food Plants. Proceeding of a workshop held in Harare, Zimbabwe, 4-6 Sept. 2001.

Manandhar, N.P. 1995. Ethnobotanical notes on unexploited wild food plants of Nepal. Ethnobotany 7:95-101.

Manandhar, N.P. 2002. Plants and People of Nepal. Timber Press, Portland, Oregon.

Melnyk, M. 1994. Biodiversity's contribution to rural livelihoods: A component of environmental impact assessment. Pp. 347-351 in Widening Perspectives on Biodiversity. Edited by A.F. Krattiger, J.A. McNeely, W.H. Lesser \& K.R. Miller. IUCN, International Academy of the Environment, Geneva.

Ngugi, G. 2000. Case study from Kenya on indigenous wild vegetables. Pp. 29-41 in Proceeding of the Workshop in Exploring the Potential of Indigenous Wild Food Plants in Southern Sudan. Edited by B. Grosskinsky \& C. Gullick. Lokochoggio, Kenya, June 3-5, 1999. The Mitchell Group, Inc., Washington, DC.

Ogle, B.M. 2001. Wild Vegetables and Micronutrient Nutrition: Studies on the significance of wild vegetables in women's diet in Vietnam. Comprehensive summaries of Uppsala dissertations from the faculty of medicine number 1056. Acta Universitatis Upsaliensis, Uppsala, Sweden.

Ogle, B.M., H.T. Tuyet, H.N. Duyet \& N.N. Xuan Duang. 2003. Food, feed or medicine: The multiple functions of edible wild plants in Vietnam. Economic Botany 57:103117.

Regmi, B.R., K.P. Aryal \& A. Subedi. 2003. Shifting Cultivation Practice and Innovation in Nepal. LI-BIRD working paper (Unpublished). Local Initiatives for Biodiversity, Research and Development (LI-BIRD), Pokhara, Nepal.

Regmi, B.R., K.P. Aryal, B.B. Tamang \& P.K. Shrestha. 2006. Homegardens: An Opportunity to minimize pressure on slash and burn system and options for improving dietary diversity of Chepang households. Pp. 35-47 in Enhancing the Contribution of Home Gardens to OnFarm Management of Plant Genetic Resources and to Improve the Livelihoods of Nepalese Farmers: Lessons learned and policy implications. Proceedings of home garden workshop, 6-7 August 2004, Pokhara, Nepal. Edited by R. Gautam, B.R. Sthapit \& P.K. Shrestha. LI-BIRD, Bioversity International and SDC, Kathmandu.

Rijal, D.K., K.B. Kadayat, K.P. Baral, Y.R. Pandey, R.B. Rana, A. Subedi, K.D. Joshi, K.K. Sherchand \& B.R. Sthapit. 1998. Diversity fairs strengthens on-farm conservation. APO Newsletter 26.

Rimal, G., S. Rimal \& R. Rimal. 2002. Nepal District Profile: A district wise socioeconomic profile along with a comprehensive national profile. National Development Institute, Kathmandu.

Scoones, I. Melnyk, M. and Pretty J. N. 1992. The hidden harvest: Wild foods and Agriculture systems. A literature review and annotated bibliography. WWF, SIDA, IIED, London.

Shore, K. 2000. Protecting uncultivated food sources in south Asia (http://www.idrc.ca/en/ev-5295-201-1-DO_ TOPIC.html (Accessed 15 March 2007).

Shrestha P.M. \& S.S. Dhillion. 2003. Medicinal plant diversity and use in the highlands of Dolakha District, Nepal. Journal of Ethnopharmacology 86:81-96.

Shrestha, P.M. \& S.S. Dhillion. 2006. Diversity and traditional knowledge concerning wild food species in a locally managed forest in Nepal. Agroforestry Systems 66:5563.

Shrestha, S.R. 2001. The state of Uncultivated Foods in Nepal Biodiversity and Uncultivated food plants. Pp. 3339 in The Proceedings of the Regional Workshop on Uncultivated Foods and Biodiversity. Edited by M.M. Johnston. September 24 to 26, Kathmandu, Nepal. USC Canada-Nepal, Kathmandu.

Smith, G.C., M.S. Clegg, C.L. Keen \& L.E. Grivett. 1995. Mineral values of selected plant foods common to Southern Burkina Faso and Niamey, Niger, West Africa. International Journal of Food Science and Nutrition 47:41-53.

Sthapit, B., D. Rijal, N. Ngoc De \& D. Jarvis. 2003. A role for diversity fairs: Experiences from Nepal and Vietnam. Pp. 271-276 in Conservation and Sustainable use of Biodiversity. A source book. Strengthening local management of biodiversity. Edited by International Potato Center. CIPUPWARD, Los Baños, Philippines.

Sullivan, S. 2000. Gender, ethnographic myths and community-based conservation in a former Namibian 'homeland'. Pp 142-164 in Rethinking Pastoralism in Africa: Gender, Culture and the Myth of the Patriarchal Pastoralist. Edited by D. Hodgson. James Currey, Oxford. 


\section{Aryal et al. - Uncultivated Plants and Livelihood Support - A case study from the Chepang people of Nepal}

Tabuti, J.R.S., S.S. Dhillon \& K.A. Lye. 2004. The status of wild food plants in Bulamogi Country, Uganda. International Journal of Food Science Nutrtion 55:485-498.

Vázquez-García, V., M. de Lourdes Godínez-Guevara, A.S. Ortiz-Gómez, \& M. Montes-Estrada. 2004. Uncultivated foods in Southern Veracruz, Mexico: Establishing the links between ecosystem health, food availability, and human nutrition. EcoHealth 1(supplement 2):131-143.

Warinwa, F. 2000. Global overview. Pp. 7-8 in Proceeding of the Workshop in Exploring the Potential of Indigenous Wild Food Plants in Southern Sudan. Edited by B. Grosskinsky \& C. Gullick. Lokochoggio, Kenya, June 3-5, 1999. The Mitchell Group, Inc., Washington, DC. 
Appendix1. Uncultivated plant species used by Chepang in the Dhading district, Nepal. Plant names are given in Nepali (commonly used local Nepali name given by key informants). Parts used: Ba=Bark, Bu=Buds, B=Bulb, Fl=Flower, F=Fruits, L=Leaf, La=Latex, S=Seeds, Sh=Shoots, S=Stem, R=Root, W=Whole plant, O=Others; Availability: $1=F a i r l y$ enough, 2=Medium, 3=Low. Specimens of uncultivated plant species were collected, identified, and vouchers were deposited at the district office of Nepal Chepang Association (NCA)

\begin{tabular}{|c|c|c|c|c|c|c|c|c|c|c|c|c|c|c|c|}
\hline \multirow{2}{*}{$\begin{array}{l}\text { Nepali } \\
\text { name }\end{array}$} & \multirow{2}{*}{$\begin{array}{l}\text { Chepang } \\
\text { name }\end{array}$} & \multirow{2}{*}{$\begin{array}{l}\text { English } \\
\text { name }\end{array}$} & \multirow[t]{2}{*}{ Scientic name } & \multirow[b]{2}{*}{$\begin{array}{l}\frac{\pi}{0} \\
\frac{\pi}{\pi}\end{array}$} & \multirow[b]{2}{*}{ 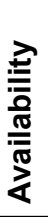 } & \multicolumn{9}{|c|}{ Uses } & \multirow[b]{2}{*}{ 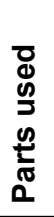 } \\
\hline & & & & & & $\begin{array}{l}\frac{1}{0} \\
\frac{0}{0} \\
\text { 눈 }\end{array}$ & 음 & 壹 & 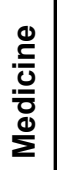 & 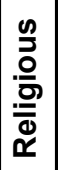 & $\begin{array}{l}\text { d } \\
.00 \\
\text { के }\end{array}$ & 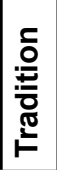 & 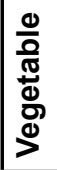 & 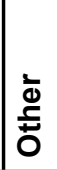 & \\
\hline $\begin{array}{l}\text { Ainselu } \\
\text { (Red) }\end{array}$ & Lyangsai & Raspberry & $\begin{array}{l}\text { Rubus acuminatus Sm. } \\
\text { Rosaceae }\end{array}$ & $\mathrm{P}$ & 3 & & $x$ & & & & & & & & $F$ \\
\hline Ainselu & Lyangsai & Raspberry & $\begin{array}{l}\text { Rubus ellipticus } \\
\text { Sm. Rosaceae }\end{array}$ & $\mathrm{P}$ & 2 & & $x$ & & & & & & & & $F$ \\
\hline Amala & Amala & $\begin{array}{l}\text { Emblic } \\
\text { myrobalan }\end{array}$ & $\begin{array}{l}\text { Phyllanthus emblica L. } \\
\text { Phyllanthaceae }\end{array}$ & $\mathrm{P}$ & 2 & & $x$ & & $x$ & & & & & $\mathrm{X}$ & $F$ \\
\hline Amaro & Pakmaru & $\begin{array}{l}\text { Golden } \\
\text { apple }\end{array}$ & $\begin{array}{l}\text { Spondias cytherea } \\
\text { Sonn. Anacardiaceae }\end{array}$ & $\mathrm{P}$ & 3 & & $x$ & & $x$ & & & & & & $F$ \\
\hline Amrisho & Phek & $\begin{array}{l}\text { Broom } \\
\text { grass }\end{array}$ & $\begin{array}{l}\text { Thysanolaena } \\
\text { maxima (Roxb.) } \\
\text { Kuntze Poaceae }\end{array}$ & $P$ & 2 & $x$ & & & & & & & & $x$ & $\begin{array}{l}S \\
L\end{array}$ \\
\hline Badhar & Dhausi & $\begin{array}{l}\text { Monkey } \\
\text { jack }\end{array}$ & $\begin{array}{l}\text { Artocarpus lokoocha Roxb. } \\
\text { Moraceae }\end{array}$ & $\mathrm{P}$ & 2 & & $x$ & & & & & & & $\mathrm{X}$ & $\begin{array}{l}F \\
L\end{array}$ \\
\hline Ban kera & Ban maisai & Banana & $\begin{array}{l}\text { Musa balbisiana Colla. } \\
\text { Musaceae }\end{array}$ & $P$ & 3 & & $x$ & & & & & & & & $F$ \\
\hline Ban tarul & Brangoi & Wild yam & $\begin{array}{l}\text { Dioscorea bulbifera L. } \\
\text { Dioscoreaceae }\end{array}$ & $\mathrm{P}$ & 3 & & $x$ & & & $x$ & & & & $x$ & $B$ \\
\hline Bankakri & Banaisai & - & $\begin{array}{l}\text { Solena heterophylla } \\
\text { Lour.Cucurbitaceae }\end{array}$ & $A$ & 2 & & $x$ & & & & & & $x$ & & $F$ \\
\hline Bans & Chyas & Bamboo & $\begin{array}{l}\text { Bambusa nepalensis } \\
\text { Stapleton } \\
\text { Poaceae }\end{array}$ & $P$ & 2 & $x$ & $x$ & & & & & & & $x$ & $\begin{array}{l}\text { Sh } \\
\text { S }\end{array}$ \\
\hline Bayar & Bayar & Bayar & $\begin{array}{l}\text { Zizyphus mauritiana Lam. } \\
\text { Rhamnaceae }\end{array}$ & $\mathrm{P}$ & 2 & & & $x$ & & & & & & $\mathrm{X}$ & $F$ \\
\hline Bel & Bel & $\begin{array}{l}\text { Wood } \\
\text { apple }\end{array}$ & $\begin{array}{l}\text { Aegle marmelos (L.) Corrêa } \\
\text { Rutaceae }\end{array}$ & $A$ & 2 & & & & & $x$ & & & & $x$ & $\begin{array}{l}\mathrm{F} \\
\mathrm{L}\end{array}$ \\
\hline Bethe sag & Bethu & $\begin{array}{l}\text { Lamb's } \\
\text { quarter }\end{array}$ & $\begin{array}{l}\text { Chenopodium album } \\
\text { L. Chenopodiaceae }\end{array}$ & $A$ & 1 & & & & & & & & $x$ & & Sh \\
\hline Bhakyamlo & Rusai & $\begin{array}{l}\text { Nepalese } \\
\text { sumac }\end{array}$ & $\begin{array}{l}\text { Rhus javanica L. } \\
\text { Anacardiaceae }\end{array}$ & $P$ & 3 & & & & $x$ & $X$ & & & & & $F$ \\
\hline $\begin{array}{l}\text { Bhimsen } \\
\text { pati }\end{array}$ & Goihomro & $\begin{array}{l}\text { Butterfly } \\
\text { bush }\end{array}$ & $\begin{array}{l}\text { Buddleja asiatica Lour. } \\
\text { Scrophulariaceae }\end{array}$ & $\mathrm{P}$ & 2 & & & & $x$ & $x$ & & & & & $L$ \\
\hline Bhorla & Maklo & $\begin{array}{l}\text { Camel's } \\
\text { foot climber }\end{array}$ & $\begin{array}{l}\text { Bauhinia vahlii Wight \& Am. } \\
\text { Fabaceae }\end{array}$ & $A$ & 2 & & & $x$ & & & & & $X$ & & $\begin{array}{l}\mathrm{F}, \\
\mathrm{Te}\end{array}$ \\
\hline Bhuin kafal & Salyangsai & - & $\begin{array}{l}\text { Fragaria daltoniana J. Gay } \\
\text { Rosaceae }\end{array}$ & A & 2 & & & $x$ & & & & & & & $F$ \\
\hline Bhyakur & Pass & $\begin{array}{l}\text { Cush-cush } \\
\text { yam }\end{array}$ & $\begin{array}{l}\text { Dioscorea deltoidea Wall. } \\
\text { ex Griseb. Dioscoreaceae }\end{array}$ & $\begin{array}{l}A \\
P\end{array}$ & 2 & & $x$ & & & & & $x$ & & & $B$ \\
\hline Bojho & Bojo & Sweet Flag & $\begin{array}{l}\text { Acorus calamus } \\
\text { L. Acoraceae }\end{array}$ & A & 2 & & & & $x$ & & & & & & C \\
\hline
\end{tabular}


Aryal et al. - Uncultivated Plants and Livelihood Support -
A case study from the Chepang people of Nepal

\begin{tabular}{|c|c|c|c|c|c|c|c|c|c|c|c|c|c|c|c|}
\hline \multirow{2}{*}{$\begin{array}{l}\text { Nepali } \\
\text { name }\end{array}$} & \multirow{2}{*}{$\begin{array}{l}\text { Chepang } \\
\text { name }\end{array}$} & \multirow{2}{*}{$\begin{array}{l}\text { English } \\
\text { name }\end{array}$} & \multirow[t]{2}{*}{ Scientic name } & & \multirow[b]{2}{*}{ 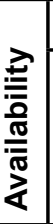 } & \multicolumn{9}{|c|}{ Uses } & \multirow[b]{2}{*}{ 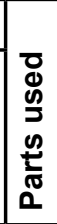 } \\
\hline & & & & & & 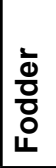 & ¿ & $\frac{5}{\frac{2}{2}}$ & 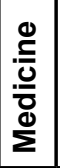 & 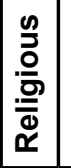 & $\begin{array}{l}\mathscr{0} \\
\text { के } \\
\text { के }\end{array}$ & 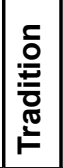 & $\left|\begin{array}{l}0 \\
\frac{0}{0} \\
\frac{0}{\pi} \\
0 \\
0 \\
0 \\
\end{array}\right|$ & 这 & \\
\hline Camuna & Camuna & - & $\begin{array}{l}\text { Syzygium cerasoides } \\
\text { (Roxb.) Raizada Myrtaceae }\end{array}$ & $P$ & 2 & & & $x$ & $x$ & & & & & & $\begin{array}{l}\mathrm{F} \\
\mathrm{Ba}\end{array}$ \\
\hline $\begin{array}{l}\text { Chalne } \\
\text { sisnu }\end{array}$ & Bannelau & $\begin{array}{l}\text { China } \\
\text { grass }\end{array}$ & $\begin{array}{l}\text { Boehmeria platyphylla } \\
\text { Buch.-Ham. ex D. } \\
\text { Don Urticaceae }\end{array}$ & $P$ & 2 & & & & $x$ & $x$ & & & & & $\begin{array}{l}\mathrm{L} \\
\mathrm{FI}\end{array}$ \\
\hline Chariamilo & - & $\begin{array}{l}\text { Creeping } \\
\text { sorrel }\end{array}$ & $\begin{array}{l}\text { Oxalis corniculata L. } \\
\text { Oxalidaceae }\end{array}$ & $A$ & 3 & & & $x$ & $x$ & & & & & & $L$ \\
\hline Chilaune & Kyangsi & $\begin{array}{l}\text { Needle } \\
\text { wood }\end{array}$ & $\begin{array}{l}\text { Schima wallichii (DC.) Korth. } \\
\text { Theaceae }\end{array}$ & $\mathrm{P}$ & 3 & & & & $x$ & $x$ & & & & & $B$ \\
\hline Chiraito & Chiraito & Chiretta & $\begin{array}{l}\text { Swertia chirayita (Roxb. } \\
\text { ex Fleming) Karsten } \\
\text { Gentianaceae }\end{array}$ & $A$ & 3 & & & & $x$ & & & & & & W \\
\hline Chiuri & Yosai & Butter tree & $\begin{array}{l}\text { Diploknema butyracea } \\
\text { (Roxb.) H.J. Lam } \\
\text { Sapotaceae }\end{array}$ & $P$ & 2 & $x$ & & $x$ & & & & $x$ & & & $\begin{array}{l}\mathrm{F} \\
\mathrm{Se} \\
\mathrm{L}\end{array}$ \\
\hline Dante okhar & - & $\begin{array}{l}\text { Thin- } \\
\text { shelled } \\
\text { walnut }\end{array}$ & $\begin{array}{l}\text { Juglans regia L. } \\
\text { Juglandaceae }\end{array}$ & $\mathrm{P}$ & 2 & & & $x$ & & $x$ & & & & & $F$ \\
\hline Dumri & Dumri & Cluster fig & $\begin{array}{l}\text { Ficus racemosa } \\
\text { L. Moraceae }\end{array}$ & $P$ & 2 & $x$ & $x$ & & & & & & & & $\mathrm{~F}$ \\
\hline Ganja & Banjorok & $\begin{array}{l}\text { Indian } \\
\text { hemp }\end{array}$ & $\begin{array}{l}\text { Cannabis sativa L. } \\
\text { Cannabaceae }\end{array}$ & $A$ & 3 & & & & $x$ & & $x$ & & & & $\mathrm{Se}$ \\
\hline Ghod tapre & Tokre jhar & $\begin{array}{l}\text { Water } \\
\text { pennywort }\end{array}$ & $\begin{array}{l}\text { Centella asiatica (L.) Urb. } \\
\text { Apiaceae }\end{array}$ & $\mathrm{P}$ & 2 & & & & $x$ & & & & & & $R$ \\
\hline Gayo & Rabe ghas & $\begin{array}{l}\text { Gambles } \\
\text { man }\end{array}$ & $\begin{array}{l}\text { Bridelia retusa (L.) A. Juss. } \\
\text { Euphorbiaceae }\end{array}$ & $P$ & 2 & $x$ & & & & $x$ & & & & & S \\
\hline Ghiukumari & - & Indian Aloe & $\begin{array}{l}\text { Aloe vera (L.) Burm.f. } \\
\text { Asphodelaceae }\end{array}$ & $\mathrm{P}$ & 2 & & & & $x$ & & & & & $x$ & $L$ \\
\hline Githa & Lak & Air potato & $\begin{array}{l}\text { Dioscorea bulbifera } \\
\text { L. Dioscoreaceae }\end{array}$ & $A$ & 2 & & $x$ & & & & & $x$ & $x$ & & $B$ \\
\hline Gogan & Omsi & - & $\begin{array}{l}\text { Saurauia napaulensis DC. } \\
\text { Actinidiaceae }\end{array}$ & $P$ & 2 & $x$ & & & & & & & & & \\
\hline Gujargano & Gujargano & Velvet leaf & $\begin{array}{l}\text { Cissampelos pareira L. } \\
\text { Menispermaceae }\end{array}$ & $\mathrm{P}$ & 3 & & & & $x$ & & & & & & W \\
\hline $\begin{array}{l}\text { Gurjo ko } \\
\text { iahara }\end{array}$ & Jyumra & Guancha & $\begin{array}{l}\text { Tinospora sinensis } \\
\text { (Lour.) Merr. } \\
\text { Menispermaceae } \\
\end{array}$ & $P$ & 2 & & & & $x$ & & & & & $x$ & W \\
\hline Hadchur & - & Mistletoe & $\begin{array}{l}\text { Viscum album L. } \\
\text { Santalaceae }\end{array}$ & $P$ & 2 & & & & $x$ & & & & & & W \\
\hline Harro & Lisai & - & $\begin{array}{l}\text { Terminalia chebula } \\
\text { Retz.Combretaceae }\end{array}$ & $P$ & 2 & & & & $x$ & & & & & $x$ & $\mathrm{~F}$ \\
\hline Imli, Titri & - & Tamarind & $\begin{array}{l}\text { Tamarindus indica } \\
\text { L. Fabaceae }\end{array}$ & $P$ & 1 & & & $x$ & & & & & & $x$ & $\mathrm{~F}$ \\
\hline Jaluko & Fyaksa & - & $\begin{array}{l}\text { Remusatia vivipara (Roxb.) } \\
\text { Schott Araceae }\end{array}$ & $A$ & 1 & & & & & & & & $x$ & & Sh \\
\hline
\end{tabular}




\begin{tabular}{|c|c|c|c|c|c|c|c|c|c|c|c|c|c|c|c|}
\hline \multirow{2}{*}{$\begin{array}{l}\text { Nepali } \\
\text { name }\end{array}$} & \multirow{2}{*}{$\begin{array}{l}\text { Chepang } \\
\text { name }\end{array}$} & \multirow{2}{*}{$\begin{array}{l}\text { English } \\
\text { name }\end{array}$} & \multirow[t]{2}{*}{ Scientic name } & & \multirow[b]{2}{*}{ 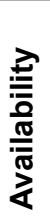 } & \multicolumn{9}{|c|}{ Uses } & \multirow[b]{2}{*}{ 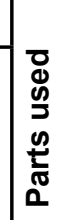 } \\
\hline & & & & & & $\begin{array}{l}\bar{\sigma} \\
\frac{0}{0} \\
0 \\
\\
\end{array}$ & $\begin{array}{l}8 \\
\vdots \\
\end{array}$ & 蒙 & 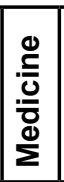 & 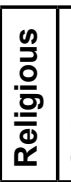 & $\frac{\mathscr{0}}{0}$ & 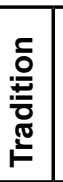 & \begin{tabular}{l|}
$\frac{0}{0}$ \\
$\frac{0}{\pi}$ \\
$\frac{\pi}{0}$ \\
$\stackrel{\circ}{\circ}$ \\
\end{tabular} & 㐫 & \\
\hline \multirow[t]{2}{*}{ Jamun } & - & Black plum & $\begin{array}{l}\text { Eugenia formosa Wall. } \\
\text { Myrtaceae. }\end{array}$ & $P$ & 2 & & & $x$ & & & & & & & $F$ \\
\hline & - & \begin{tabular}{|l|} 
Indian \\
gooseberry
\end{tabular} & $\begin{array}{l}\text { Syzygium cumini (L.) Skeels } \\
\text { Myrtaceae. }\end{array}$ & $P$ & 2 & $x$ & $x$ & & & & & & & & $\mathrm{~F}$ \\
\hline $\begin{array}{l}\text { Jangali } \\
\text { aanp }\end{array}$ & Bantaksai & \begin{tabular}{|l} 
Wild \\
mango
\end{tabular} & $\begin{array}{l}\text { Mangifera indica L. } \\
\text { Anacardiaceae }\end{array}$ & $P$ & 3 & & & $x$ & & & & & & $x$ & $F$ \\
\hline Jaringo & - & $\begin{array}{l}\text { Poker } \\
\text { weed }\end{array}$ & $\begin{array}{l}\text { Phytolacca acinosa } \\
\text { Roxb.Phytolaccaceae }\end{array}$ & $\begin{array}{l}\mathrm{A} \\
\mathrm{P}\end{array}$ & 3 & & & & & & & & $x$ & & $L$ \\
\hline Kabro & Kabra & $\begin{array}{l}\text { Elephant } \\
\text { fig }\end{array}$ & $\begin{array}{l}\text { Ficus lacor Buch.-Ham. } \\
\text { Moraceae }\end{array}$ & $P$ & 2 & $x$ & & & & & & & $x$ & & $\mathrm{Bu}$ \\
\hline Kali nieuro & $\begin{array}{l}\text { Galo } \\
\text { nenggarya }\end{array}$ & Fern & $\begin{array}{l}\text { Tectaria macrodonta (Fée) } \\
\text { C. Chr. Aspidiaceae }\end{array}$ & $A$ & 3 & & & & $x$ & & & & $x$ & & $S h$ \\
\hline Kansi amala & - & \begin{tabular}{|l|} 
Star \\
gooseberry
\end{tabular} & $\begin{array}{l}\text { Phyllanthus acidus (L.) } \\
\text { Skeels Phyllanthaceae }\end{array}$ & $P$ & 3 & & & $x$ & & & & & & & $F$ \\
\hline Kaphal & Kaphal & Box myrtle & $\begin{array}{l}\text { Myrica esculenta Buch.- } \\
\text { Ham. ex D. Don Myrtcaceae }\end{array}$ & $A$ & 1 & & & $x$ & & & & & & & $\mathrm{~F}$ \\
\hline Katus & Ekai & Chestnut & $\begin{array}{l}\text { Castanopsis indica (Roxb. } \\
\text { ex Lindl.) A. DC. Fagaceae }\end{array}$ & $P$ & 2 & & & $x$ & & $x$ & & & & & $F$ \\
\hline $\begin{array}{l}\text { Khaniyo } \\
\text { (Rai) }\end{array}$ & Koksai & - & $\begin{array}{l}\text { Ficus semicordata Buch.- } \\
\text { Ham.ex Sm. Moraceae }\end{array}$ & $P$ & 1 & $x$ & & $x$ & & & & & & & $\begin{array}{l}\mathrm{F} \\
\mathrm{L}\end{array}$ \\
\hline Kharane & Kharane & - & $\begin{array}{l}\text { Viburnum cylindricum } \\
\text { Buch.-Ham. ex D. } \\
\text { Don Caprifoliaceae }\end{array}$ & $P$ & 2 & & $\mathrm{X}$ & & $x$ & & & & & & Sh \\
\hline Khasreto & Cheksi & Hairy fig & Ficus hispida L.f. Moraceae & $\mathrm{P}$ & 2 & $x$ & & $x$ & & & & & & & $L$ \\
\hline Khirro & Miktalang & - & $\begin{array}{l}\text { Sapium insigne (Royle) } \\
\text { Benth. \& Hook.f. } \\
\text { Euphorbiaceae }\end{array}$ & $P$ & 2 & $x$ & & & $x$ & & & & & & $\begin{array}{l}\mathrm{L} \\
\mathrm{Ba}\end{array}$ \\
\hline Khole sag & Simsag & Brooklime & $\begin{array}{l}\text { Veronica beccabunga L. } \\
\text { Scrophulariaceae }\end{array}$ & $A$ & 1 & & & & & & & & $x$ & & $\mathrm{~L}$ \\
\hline Kimbu & Nemaksai & Mulberry & Morus alba L. Moraceae & $P$ & 2 & $x$ & $\mathrm{X}$ & & & & & & & & $\begin{array}{l}F \\
L \\
R\end{array}$ \\
\hline Koiralo & Rimsi & - & $\begin{array}{l}\text { Bauhinia purpurea } \\
\text { L. Fabaceae }\end{array}$ & $\mathrm{P}$ & 1 & $x$ & & & & & & & $x$ & & $\mathrm{Bu}$ \\
\hline Kurilo & Jyordum & $\begin{array}{l}\text { Wild } \\
\text { asparagus }\end{array}$ & $\begin{array}{l}\text { Asparagus racemosus Willd. } \\
\text { Asparagaceae }\end{array}$ & $\begin{array}{l}A \\
P\end{array}$ & 3 & & & & $\mathrm{x}$ & & & & $x$ & $x$ & Sh \\
\hline Kutilkosa & Nakatisai & $\begin{array}{l}\text { Clover } \\
\text { vetch }\end{array}$ & $\begin{array}{l}\text { Vicia angustifolia L. ex } \\
\text { Reichard Fabaceae }\end{array}$ & $A$ & 1 & $x$ & $x$ & & & & & & & & $\begin{array}{l}F \\
W\end{array}$ \\
\hline Lapsi & Lapsi & Monbin & $\begin{array}{l}\text { Choerospondias axillaris } \\
\text { (Roxb.) B.L. Burtt \& A.W. Hill } \\
\text { Anacardiaceae }\end{array}$ & $P$ & 2 & & & $x$ & & & & & & $x$ & $F$ \\
\hline Latte sag & Dakhinsag & Amaranth & $\begin{array}{l}\text { Amaranthus spinosus L. } \\
\text { Amaranthaceae }\end{array}$ & $A$ & 1 & & & & & & & & $x$ & $x$ & Sh \\
\hline Lunde & Armulya & Pigweed & $\begin{array}{l}\text { Amaranthus viridis } \mathrm{L} \text {. } \\
\text { Amaranthaceae }\end{array}$ & $A$ & 1 & & & & & & & & $x$ & & Sh \\
\hline
\end{tabular}


Aryal et al. - Uncultivated Plants and Livelihood Support -

A case study from the Chepang people of Nepal

\begin{tabular}{|c|c|c|c|c|c|c|c|c|c|c|c|c|c|c|c|}
\hline \multirow{2}{*}{$\begin{array}{l}\text { Nepali } \\
\text { name }\end{array}$} & \multirow{2}{*}{$\begin{array}{l}\text { Chepang } \\
\text { name }\end{array}$} & \multirow{2}{*}{$\begin{array}{l}\text { English } \\
\text { name }\end{array}$} & \multirow[t]{2}{*}{ Scientic name } & \multirow[b]{2}{*}{$\frac{\frac{5}{0}}{\frac{\pi}{1}}$} & \multirow[b]{2}{*}{ 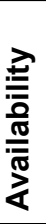 } & \multicolumn{9}{|c|}{ Uses } & \multirow[b]{2}{*}{ 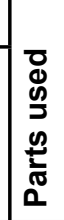 } \\
\hline & & & & & & 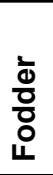 & $\begin{array}{l} \\
\\
\\
\end{array}$ & 蒙 & 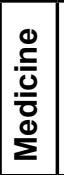 & 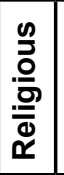 & $\frac{\mathscr{\infty}}{0}$ & 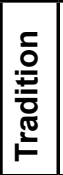 & \begin{tabular}{|l|}
$\frac{0}{0}$ \\
$\frac{0}{\pi}$ \\
$\frac{0}{0}$ \\
0 \\
\end{tabular} & 㐫 & \\
\hline $\begin{array}{l}\text { Marcha } \\
\text { Jhar }\end{array}$ & Michyano & Iron weed & $\begin{array}{l}\text { Vernonia cinerea (L.) Less. } \\
\text { Asteraceae }\end{array}$ & $A$ & 1 & & & & $x$ & & & & & $x$ & $L$ \\
\hline Mel & Mayal & Wild pear & $\begin{array}{l}\text { Pyrus pashia Buch.-Ham. } \\
\text { ex D.Don Rosaceae }\end{array}$ & $P$ & 3 & & $x$ & & & $x$ & & & $x$ & & $\begin{array}{l}F \\
S\end{array}$ \\
\hline Nigalo & Monyanro & $\begin{array}{l}\text { Himalayan } \\
\text { bamboo }\end{array}$ & $\begin{array}{l}\text { Arundinaria falcata Nees } \\
\text { Poaceae }\end{array}$ & $P$ & 2 & $x$ & & & & & & & & $x$ & $S$ \\
\hline Nimaro & Nemsi & $\begin{array}{l}\text { Eve's } \\
\text { apron }\end{array}$ & $\begin{array}{l}\text { Ficus auriculata Lour. } \\
\text { Moraceae }\end{array}$ & $P$ & 2 & $x$ & & $x$ & & & & & & & $\begin{array}{l}F \\
\mathrm{~L}\end{array}$ \\
\hline Niuro & Niuro & Edible fern & $\begin{array}{l}\text { Dryopteris cochleata } \\
\text { (D. Don) C. Chr. } \\
\text { Dryopteridaceae } \\
\end{array}$ & $A$ & 3 & & & & $x$ & & & & $x$ & & Sh \\
\hline Pakhanbed & Pakhanbed & Rock foil & $\begin{array}{l}\text { Bergenia ciliata } \\
\text { (Haw.) Sternb. } \\
\text { Saxifragaceae }\end{array}$ & $P$ & 2 & & & & $x$ & & & & & & W \\
\hline Pandel & Yausi & - & $\begin{array}{l}\text { Ziziphus incurva Roxb. } \\
\text { Rhamnaceae }\end{array}$ & $P$ & 2 & $x$ & & $x$ & & & & & & & $F$ \\
\hline Pani amala & Tisai & Fern & $\begin{array}{l}\text { Nephrolepis cordifolia (L.) } \\
\text { C. Presl. Nephrolepidaceae }\end{array}$ & $P$ & 2 & & & $x$ & & & & & & & $\mathrm{~F}$ \\
\hline Pudina & Pudina & Mint & $\begin{array}{l}\text { Mentha arvensis } \\
\text { L. Lamiaceae }\end{array}$ & $P$ & 1 & & & & $x$ & & & & & $x$ & $\mathrm{~L}$ \\
\hline Raikhanyu & Koksi & $\begin{array}{l}\text { Nepal } \\
\text { fodder fig }\end{array}$ & $\begin{array}{l}\text { Ficus semicordata } \\
\text { Buch.-Ham. } \\
\text { ex Sm. Moraceae }\end{array}$ & $P$ & 2 & $x$ & & $x$ & & & & & & & $\begin{array}{l}F \\
L\end{array}$ \\
\hline Ratigeri & Ratigeri & Bead vine & $\begin{array}{l}\text { Abrus precatorius } \\
\text { L. Fabaceae }\end{array}$ & $P$ & 2 & & $x$ & & $x$ & & & & & & $\begin{array}{l}\mathrm{F} \\
\mathrm{Ba}\end{array}$ \\
\hline Rudilo & Nampuni & - & $\begin{array}{l}\text { Pogostemon glaber Benth. } \\
\text { Lamiaceae }\end{array}$ & $P$ & 2 & & & & $x$ & & & & & & W \\
\hline Sal & Raksi & Sal & $\begin{array}{l}\text { Shorea robusta Gaertn. } \\
\text { Dipterocarpaceae }\end{array}$ & $P$ & 2 & & & & & $x$ & & & & $x$ & $\begin{array}{l}\mathrm{La} \\
\mathrm{L}\end{array}$ \\
\hline $\begin{array}{l}\text { Shikari } \\
\text { lahara }\end{array}$ & $\begin{array}{l}\text { Sikari } \\
\text { lahara }\end{array}$ & & $\begin{array}{l}\text { Periploca calophylla (Wight) } \\
\text { Falc. Apocynaceae }\end{array}$ & $P$ & 2 & & & & $x$ & & & & & & W \\
\hline Shiplican & Dyoyaisag & Garlic pear & $\begin{array}{l}\text { Crataeva unilocularis } \\
\text { Buch.-Ham. Capparaceae }\end{array}$ & $P$ & 1 & & & & & & & & $x$ & $x$ & $\mathrm{Bu}$ \\
\hline Sim sag & Papinja & $\begin{array}{l}\text { Water } \\
\text { cress }\end{array}$ & $\begin{array}{l}\text { Rorippa nasturtium- } \\
\text { aquaticum (L.) Hayek } \\
\text { Brassicaceae }\end{array}$ & $A$ & 2 & & & & & & & & $x$ & & $L$ \\
\hline Simali & Glausigoi & $\begin{array}{l}\text { Orange } \\
\text { jasmine }\end{array}$ & $\begin{array}{l}\text { Murraya paniculata (L.) } \\
\text { Jack Rutaceae }\end{array}$ & $P$ & 2 & & & & $x$ & & & & & & $S$ \\
\hline Sisno & Nelau & Nettle & Urtica dioica L. Urticaceae & $\mathrm{P}$ & 1 & & & & $x$ & & & & $x$ & & $\begin{array}{l}\mathrm{L} \\
\mathrm{Sh}\end{array}$ \\
\hline Siundi & Kituki & - & $\begin{array}{l}\text { Euphorbia sp. } \\
\text { Euphorbiaceae }\end{array}$ & $P$ & 2 & & & & $x$ & $x$ & & & & & $\begin{array}{l}\mathrm{F} \\
\mathrm{S}\end{array}$ \\
\hline Tanki & Saga & $\begin{array}{l}\text { Pink } \\
\text { bauhinia }\end{array}$ & $\begin{array}{l}\text { Bauhinia purpurea } \\
\text { L. Fabaceae }\end{array}$ & $P$ & 1 & $x$ & & & & & & & $x$ & & $\begin{array}{l}\mathrm{Bu} \\
\mathrm{F}\end{array}$ \\
\hline
\end{tabular}




\begin{tabular}{|c|c|c|c|c|c|c|c|c|c|c|c|c|c|c|c|}
\hline \multirow{2}{*}{$\begin{array}{l}\text { Nepali } \\
\text { name }\end{array}$} & \multirow{2}{*}{$\begin{array}{l}\text { Chepang } \\
\text { name }\end{array}$} & \multirow{2}{*}{$\begin{array}{l}\text { English } \\
\text { name }\end{array}$} & \multirow[t]{2}{*}{ Scientic name } & \multirow[b]{2}{*}{$\frac{\pi}{\frac{\pi}{\pi}}$} & \multirow[b]{2}{*}{ 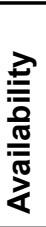 } & \multicolumn{9}{|c|}{ Uses } & \multirow[b]{2}{*}{ 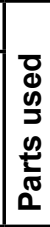 } \\
\hline & & & & & & \begin{tabular}{|l|} 
\\
$\overline{0}$ \\
$\overline{0}$ \\
$\dot{0}$ \\
\end{tabular} & $\begin{array}{l} \\
: \\
\circ \\
\end{array}$ & $\frac{5}{\frac{1}{2}}$ & 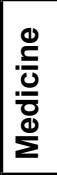 & 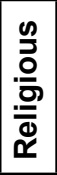 & $\frac{\mathscr{0}}{\frac{0}{0}}$ & 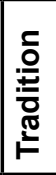 & 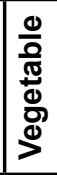 & ఏ & \\
\hline Thirjo & Khirsi & - & $\begin{array}{l}\text { Aeschynanthus } \\
\text { parviflorus (D. Don) } \\
\text { Spreng. Gesneriaceae }\end{array}$ & $\mathrm{P}$ & 2 & & & & $x$ & & & & & & $\begin{array}{l}\text { W } \\
L\end{array}$ \\
\hline Timoor & Umpur & $\begin{array}{l}\text { Nepal } \\
\text { pepper }\end{array}$ & $\begin{array}{l}\text { Zanthoxylum armatum DC. } \\
\text { Rutaceae }\end{array}$ & $P$ & 2 & & & & $x$ & & $x$ & & & & $\mathrm{~F}$ \\
\hline Tindu & Tindu & Tindu & $\begin{array}{l}\text { Diospyros malabarica } \\
\text { (Desr.) } \\
\text { Kostel. Ebenaceae }\end{array}$ & $A$ & 2 & & & $x$ & & & & & & & $F$ \\
\hline Titepati & Pati & Mug wort & $\begin{array}{l}\text { Artemisia indica } \\
\text { Wild. Asteraceae }\end{array}$ & $P$ & 1 & & & & $x$ & $x$ & & & & & L \\
\hline Tyaguna & - & - & $\begin{array}{l}\text { Dioscorea pentaphylla L. } \\
\text { Dioscoreaceae }\end{array}$ & $A$ & 2 & & $x$ & & & & & & $x$ & & $B$ \\
\hline
\end{tabular}

